\title{
The effects of low-protein diets and protease supplementation on broiler chickens in a hot and humid tropical environment
}

\author{
Fang Lin Law ${ }^{1}$, Idrus Zulkifli ${ }^{1,2,3, *}$, Abdoreza Farjam Soleimani ${ }^{1}$, Juan Boo Liang', and Elmutaz Atta Awad ${ }^{1,4}$
}

* Corresponding Author: Idrus Zulkifli Tel: +60-3-8947-1042, Fax: +60-3-8938-1612,

E-mail: zulidrus@upm.edu.my

${ }^{1}$ Institute of Tropical Agriculture and Food Security, Universiti Putra Malaysia, UPM Serdang, Selangor 43400, Malaysia

2 Department of Animal Science, Universiti Putra Malaysia, UPM Serdang, Selangor 43400, Malaysia ${ }^{3}$ Halal Products Research Institute, Universiti Putra Malaysia, UPM Serdang, Selangor 43400, Malaysia ${ }^{4}$ Department of Poultry Production, University of Khartoum, Khartoum North 13314, Sudan

ORCID

Fang Lin Law

https://orcid.org/0000-0003-0408-6334

Idrus Zulkifli

https://orcid.org/0000-0002-2082-7430

Abdoreza Farjam Soleimani

https://orcid.org/0000-0002-7637-0556

Juan Boo Liang

https://orcid.org/0000-0001-6024-0856

Elmutaz Atta Awad

https://orcid.org/0000-0002-4312-501X

Submitted Aug 5, 2017; Revised Sept 5, 2017 ; Accepted Nov 4, 2017
Objective: This experiment was conducted to investigate the effects of dietary crude protein (CP) level and exogenous protease supplementation on growth performance, serum metabolites, carcass traits, small intestinal morphology and endogenous protease activity in broiler chickens reared under a tropical climate.

Methods: A total of 480 day-old male broiler chicks were randomly assigned to eight dietary treatments in a $4 \times 2$ factorial arrangement. The main effects were CP level $(21.0 \%, 19.7 \%, 18.5 \%$, or $17.2 \%$ from 1 to 21 days and $19.0 \%, 17.9 \%, 16.7 \%$, or $15.6 \%$ from 22 to 35 days) and protease enzyme supplementation ( $0 \mathrm{ppm}$ or $500 \mathrm{ppm})$. All experimental diets were fortified with synthetic feed-grade lysine, methionine, threonine and tryptophan to provide the minimum amino acid recommended levels for Cobb 500.

Results: Reducing dietary CP linearly reduced $(\mathrm{p}<0.05)$ growth performance, serum albumin, total protein, and carcass traits and increased $(\mathrm{p}<0.05)$ serum triglycerides and abdominal fat. There was no consistent effect of reducing dietary $\mathrm{CP}$ on morphological parameters of the intestine and on the pancreatic and intestinal endogenous protease activity ( $p>0.05)$. Protease supplementation improved $(\mathrm{p}<0.05)$ feed conversion ratio, body weight gain, carcass yield and intestinal absorptive surface area.

Conclusion: Protease supplementation, as measured by growth performance, intestinal morphology and carcass yield, may alleviate the detrimental effects of low protein diets in broiler chickens.

Keywords: Broiler Chickens; Microbial Protease; Low-protein Diet; Growth Performance; Intestinal Morphology

\section{INTRODUCTION}

Cost minimization and environmental concern are consistently driving poultry nutritionists to improve the efficiency of feed utilization by formulating digestible, practical diets to avoid overfeeding with nutrients. Over the past few decades, numerous studies have been published on the use of synthetic amino acids (AAs) in low protein (LP) diets $[1,2,3]$. The supplementation of AAs in these studies varied widely depending on the type of supplemented AA, such as first and second limiting AA, feed-grade AAs, all essential amino acids (EAAs) or both EAAs and non-essential amino acids (NEAAs). However, usage of LP diets in some excessive levels still has a negative impact on growth performance, carcass traits [1], morphology of intestinal villi [4] and profitability. The scenario is more challenging when broilers are raised under high-temperature conditions, either during summer in temperate regions or in a tropical climate [5]. Although one study suggested LP diets as a means of reducing metabolic heat production associated with protein catabolism [6], others suggested the use of higher dietary crude protein $(\mathrm{CP})$ mainly due to lower feed intake (FI) and protein digestibility under high-temperature conditions [7]. It is possible that the combination of 
these two strategies results in better performance by providing an LP diet supplemented with commercially available feedgrade AA and exogenous enzymes [8-10].

Although use of exogenous enzyme blends (i.e., carbohydrases, phytase, and protease) is well-established and widely accepted to improve digestibility of nutrient elements $[8,10]$, use of single proteases is still under investigation for widespread application. Single exogenous protease, when added to the diet, effectively increased the apparent AA and protein digestibility in the broiler chicken's diet, even in an LP diet $[11,12]$. However, some reports did not confirm the conversion of those improvements in broiler performance $[13,14]$. Proteases may have an 'extra-proteinaceous' advantage for broilers reared under high temperature conditions by improving gut health [15]. Supplemental mono-component protease reduced the population of intestinal clostridium [16] and improved intestinal villi height ( $\mathrm{VH})$ and $\mathrm{VH} /$ crypt depth (CD) ratio [17] in broiler chickens.

The health and development of the intestinal epithelium and its absorptive surface area (ASA) are reported to be diminished under heat stress conditions, leading to poorer nutrient absorption and performance in broiler chickens [18]. Thus, the current study was undertaken to explore the effect of exogenous microbial protease supplementation on growth performance, blood metabolites, carcass traits and intestinal morphology in broiler chickens that were fed LP diets and reared under a hot and humid tropical climate.

\section{MATERIALS AND METHODS}

\section{Experimental design and diets}

Four isocaloric diets with descending levels of CP namely i) $21.0 \%$ (day 1 to 21 ) and $19.0 \%$ (day 22 to 35 ), ii) $19.7 \%$ (day 1 to 21 ) and $17.9 \%$ (day 22 to 35 ), iii) $18.5 \%$ (day 1 to 21 ) and $16.7 \%$ (day 22 to 35 ), iv) $17.2 \%$ (day 1 to 21 ) and $15.6 \%$ (day 22 to 35 ) were formulated. Diets were fortified with synthetic feed-grade lysine, methionine, threonine and tryptophan to provide the minimum AA recommended levels for Cobb 500 (Table 1). Four hundred and eighty birds were randomly assigned to diets without or with microbial protease $(300,000$ units $/ \mathrm{kg}$ ) supplementation from day 1 to 35 . Thus, the experiment had a $4 \times 2$ factorial arrangement of treatments with diets containing four levels of CP and two levels of enzyme supplementation. There were four replicate pens per dietary CPenzyme supplementation subgroup.

\section{Enzyme composition}

A purified microbial protease (Cibenza DP100; Novus International Inc., St. Charles, MO, USA) was used in this study. The enzyme is an alkaline serine endopeptidase protease derived from Bacillus lichenformis with a protease activity of 600,000 units/g. The manufacturer's recommended inclusion rate is 300 units/g of feed. The protease activity was determined using the method described by Jin et al [19]. The protease activity in protease-added diets for NP, LP1, LP2, and LP3 diets were $324,294,325$, and 327 units per gram of starter feed and $305,325,286$, and 321 units per gram of finisher feed, respectively.

\section{Birds and management}

All experimental procedures were conducted in accordance with Universiti Putra Malaysia Research Policy on Animal Ethics and Welfare. A total of 480 day-old male Cobb 500 broiler chicks (46.56 g \pm 0.01$)$ were randomly distributed to 32 floor pens ( $\mathrm{n}=15 \mathrm{chicks} / \mathrm{pen}$ ) with wood shavings that serve as deep litter material in a conventional open-sided poultry house and under the hot and humid tropical conditions. The temperature ranged from $23^{\circ} \mathrm{C}$ to $36^{\circ} \mathrm{C}$, and the relative humidity was between $75 \%$ and $90 \%$. Respective diets (mash feed) and water were provided ad libitum from day (d) 1 to 35.

\section{Data collection and sampling}

Birds and feed were weighed by pen group at the initial of the experiment ( $d$ 1) and the remaining of the feed and body weight were recorded on d 1, 21, and 35. Feed supple and left over of the feed consumption were weighed during the same period. The FI data was adjusted for mortalities and feed conversion ratio (FCR) was calculated as ratio of feed consumption to weight gain. Mortality was recorded as it occurred. On d 35, two birds per replicate were randomly selected, individually weighed and sacrificed for collection of blood, intestinal tissue and digesta. Blood samples were centrifuged at 3,000 g at $4^{\circ} \mathrm{C}$ for $15 \mathrm{~min}$ to obtain the serum. The haemolysis-free serum was transferred immediately and frozen at $-80^{\circ} \mathrm{C}$ until further biochemical analyses. For measurement of intestinal morphology, approximately $5 \mathrm{~cm}$ of the middle portion of the duodenum (apex section), jejunum (between the entry of bile ducts and Meckel's diverticulum) and ileum (between Meckel's diverticulum and caecal junction) were cut, gently flushed with $0.9 \%$ saline solution, and placed in $10 \%$ neutral-buffered formalin. Additionally, intestinal digesta contents from the distal end of duodenum to ileo-caecal junction and pancreas samples were collected for protease activity measurement. The pancreas and intestinal content samples were collected from each bird within 5 min after death, placed in a 5-mL screwcapped tube and immediately frozen in liquid nitrogen and then stored at $-80^{\circ} \mathrm{C}$ until further analysis.

\section{Carcass traits}

On d 36, two birds, based on the average body weight per pen, were randomly selected (eight birds/dietary treatment), legbanded, and weighed individually. Birds were slaughtered by the Halal slaughtering process. When the birds were completely immobilized, carcasses were scalded at $55^{\circ} \mathrm{C}$ to $60^{\circ} \mathrm{C}$ 
Table 1. Ingredient and nutrient compositions of experimental diets

\begin{tabular}{|c|c|c|c|c|c|c|c|c|}
\hline \multirow{2}{*}{ Item } & \multicolumn{4}{|c|}{ Starter (d 1-2) } & \multicolumn{4}{|c|}{ Finisher (d 22-35) } \\
\hline & $N P^{1)}$ & LP1 & LP2 & LP3 & NP & LP1 & LP2 & LP3 \\
\hline \multicolumn{9}{|l|}{ Ingredient (\%) } \\
\hline Corn & 59.33 & 61.33 & 63.31 & 65.35 & 61.38 & 63.01 & 64.50 & 65.97 \\
\hline Soybean meal & 32.40 & 27.15 & 21.95 & 16.65 & 27.75 & 22.35 & 17.00 & 11.75 \\
\hline Canola meal & 1.00 & 3.00 & 5.00 & 7.00 & 1.50 & 4.00 & 6.50 & 9.00 \\
\hline Palm kernel meal & 1.00 & 2.00 & 3.00 & 4.00 & 1.50 & 2.50 & 3.50 & 4.50 \\
\hline Palm olein & 2.55 & 2.56 & 2.60 & 2.65 & 4.80 & 4.90 & 5.06 & 5.17 \\
\hline Limestone & 1.31 & 1.32 & 1.32 & 1.31 & 1.12 & 1.11 & 1.11 & 1.10 \\
\hline Sodium chloride & 0.34 & 0.34 & 0.33 & 0.33 & 0.34 & 0.35 & 0.34 & 0.34 \\
\hline $\mathrm{MDCP}$ & 1.57 & 1.56 & 1.57 & 1.58 & 1.28 & 1.26 & 1.29 & 1.29 \\
\hline L-lysine & 0.13 & 0.24 & 0.34 & 0.45 & 0.01 & 0.11 & 0.22 & 0.31 \\
\hline DL-methionine & 0.21 & 0.23 & 0.26 & 0.29 & 0.18 & 0.21 & 0.23 & 0.25 \\
\hline L-threonine & 0.06 & 0.12 & 0.17 & 0.23 & - & 0.06 & 0.11 & 0.16 \\
\hline L-tryptophan & - & - & - & 0.01 & - & - & - & 0.02 \\
\hline Vitamin and mineral premix $x^{2)}$ & 0.15 & 0.15 & 0.15 & 0.15 & 0.14 & 0.14 & 0.14 & 0.14 \\
\hline \multicolumn{9}{|c|}{ Nutrient (calculated, \% unless stated otherwise) } \\
\hline Metabolisable energy (MJ/kg) & 12.71 & 12.71 & 12.71 & 12.71 & 13.31 & 13.31 & 13.31 & 13.31 \\
\hline Crude protein & 21.00 & 19.74 & 18.50 & 17.24 & 19.05 & 17.87 & 16.70 & 15.58 \\
\hline \multicolumn{9}{|l|}{ Total amino acids } \\
\hline Lysine & 1.28 & 1.28 & 1.28 & 1.28 & 1.04 & 1.04 & 1.05 & 1.04 \\
\hline Methionine & 0.53 & 0.54 & 0.56 & 0.57 & 0.48 & 0.50 & 0.51 & 0.52 \\
\hline Methionine+cysteine & 0.89 & 0.89 & 0.89 & 0.89 & 0.82 & 0.82 & 0.82 & 0.82 \\
\hline Threonine & 0.88 & 0.88 & 0.87 & 0.87 & 0.75 & 0.75 & 0.75 & 0.74 \\
\hline Tryptophan & 0.26 & 0.24 & 0.22 & 0.21 & 0.24 & 0.22 & 0.20 & 0.20 \\
\hline Valine & 1.03 & 0.96 & 0.90 & 0.83 & 0.95 & 0.88 & 0.82 & 0.76 \\
\hline Arginine & 1.47 & 1.35 & 1.24 & 1.12 & 1.33 & 1.22 & 1.11 & 1.00 \\
\hline Phenylalanine+tyrosine & 1.71 & 1.59 & 1.47 & 1.35 & 1.57 & 1.45 & 1.33 & 1.22 \\
\hline Leucine & 1.81 & 1.70 & 1.59 & 1.47 & 1.68 & 1.57 & 1.46 & 1.35 \\
\hline Isoleucine & 0.91 & 0.84 & 0.76 & 0.69 & 0.83 & 0.76 & 0.68 & 0.61 \\
\hline Histidine & 0.57 & 0.53 & 0.49 & 0.45 & 0.52 & 0.48 & 0.45 & 0.41 \\
\hline Glycine+serine & 1.89 & 1.75 & 1.62 & 1.47 & 1.72 & 1.59 & 1.46 & 1.33 \\
\hline \multicolumn{9}{|l|}{ Analysed composition (\%) } \\
\hline Crude protein & 21.59 & 19.56 & 18.41 & 17.64 & 18.70 & 17.77 & 16.66 & 15.63 \\
\hline Lysine & 1.28 & 1.15 & 1.14 & 1.17 & 1.09 & 0.96 & 1.04 & 0.97 \\
\hline Methionine & 0.46 & 0.39 & 0.42 & 0.41 & 0.43 & 0.43 & 0.40 & 0.39 \\
\hline Threonine & 0.85 & 0.84 & 0.82 & 0.86 & 0.78 & 0.75 & 0.78 & 0.72 \\
\hline
\end{tabular}

MDCP, monodicalcium phosphate; $A A$, amino acid.

1) NP, normal protein (starter CP21/finisher CP19); LP1, low protein diet 1 (starter CP19.7/finisher CP17.9); LP2, low protein diet 2 (starter CP18.5/finisher CP16.7); LP3, low protein diet 3 (starter CP17.2/finisher CP15.6).

2) Premix per kg of diet: vitamin $A, 50$ MIU: vitamin $D_{3}, 10 \mathrm{MIU}$; vitamin $\mathrm{E}_{1} 130 \mathrm{~g}$; vitamin $\mathrm{K}_{3}, 10 \mathrm{~g}$; vitamin $\mathrm{B}_{1}, 10 \mathrm{~g}$; vitamin $\mathrm{B}_{2}, 25 \mathrm{~g}$; vitamin $\mathrm{B}_{6}, 16 \mathrm{~g}$; vitamin $\mathrm{B}_{12}, 0.1 \mathrm{~g}$; biotin, $0.50 \mathrm{~g}$; folic acid, $8 \mathrm{~g}$; niacin, $200 \mathrm{~g}$; pantothenic acid, $56 \mathrm{~g}$; iron as ferrous sulphate monohydrate $110 \mathrm{~g}$; zinc as zinc oxide 110 g; manganese as manganese oxide 110 $\mathrm{g}$; copper as cupric sulphatepentahydrate $11 \mathrm{~g}$; iodine as potassium iodate $2 \mathrm{~g}$; cobalt as cobalt chelates of AA $0.3 \mathrm{~g}$; selenium as selenium chelates of AA $0.3 \mathrm{~g}$; chromium as chromium chelates of AA $0.5 \mathrm{~g}$.

for $45 \mathrm{~s}$ and defeathered in a rotary plucker. The carcass weight was recorded with abdominal fat, lungs and kidneys but without giblets, feet or the head. Non-deboned breast meat with the attached skin (both pectoralis major and minor) and abdominal fat were removed and weighed. The abdominal fat pad was considered the tissue surrounding the gizzard and intestines, extending within the scheme, neighbouring the cloaca and bursa of fabricius, and adjoining the abdominal muscle.

\section{Gut morphology}

The intestinal segments ( 2 to $4 \mathrm{~mm}$ ) were dehydrated for 16 $\mathrm{h}$ in an automatic tissue processor (Leica ASP 3000; Leica Biosystems GmbH, Nussloch, Germany) before being embedded in paraffin (Leica EG 1160; Leica Biosystems GmbH, Germany). Duplicate tissue sections with $4-\mu \mathrm{m}$ thickness were produced using a rotary microtome machine (Leica RM 2155; Leica Biosystems $\mathrm{GmbH}$, Germany). The sections were placed on a glass slide and heated at $57^{\circ} \mathrm{C}$ until dried. Upon drying, 
the slides were stained with haematoxylin-eosin and covered with a cover-slip. Histological indices were analysed under a computer-aided light microscope using image analysis (Leica Camera AG, Solms, Germany). The VH (from the crypt mouth to the villus tip), $\mathrm{CD}$ (from the base up to the region of transition between the crypt and villi) and villus width (VW) (half of the villus length) were measured. Accordingly, the apparent ASA $(\mathrm{VH} \times \mathrm{VW})$ and the $\mathrm{VH} / \mathrm{CD}$ ratio were calculated [4].

\section{Endogenous protease activity}

Pancreas tissues were processed by adding five times their weight in ice-cold $0.2 \mathrm{M}$ Tris buffer ( $\mathrm{pH} 8.0$ ) with $0.05 \mathrm{M} \mathrm{NaCl}$ and then homogenized using Ultra-Turrax homogenizer (IKA Works Inc., Wilmington, NC, USA). The homogenates were centrifuged at $3,000 \times g$ for $15 \mathrm{~min}$ at $4^{\circ} \mathrm{C}$, and the supernatant was used for protease activity measurement as described by Jin et al [19]. Digesta samples were diluted 10 times (w/v) using ice-cold phosphate-buffered saline (pH 7.0) and then homogenized and sonicated for one min with three cycles at $30 \mathrm{~s}$ intervals. The samples were later centrifuged at $18,000 \times g$ for $20 \mathrm{~min}$ at $4^{\circ} \mathrm{C}$, and the supernatants were used for the protease enzyme activity assay [19]. All procedures were handled on ice to prevent possible enzyme degradation. The protease activity unit was defined as milligrams of azocasein degraded during $2 \mathrm{~h}$ of incubation at $38^{\circ} \mathrm{C}$ per $\mathrm{mg}$ of intestinal digesta protein $(\mathrm{U} / \mathrm{mg}$ protein) or pancreas. The intestinal digesta protein concentrations were determined using colorimetric reaction of the bicinchoninic acid protein assay kit (SigmaAldrich, St. louis, MO, USA).

\section{Biochemical analysis}

Feed samples were collected and finely ground using a coffee grinder (Panasonic, Shah Alam, Selangor, Malaysia). The dry matter (DM) and CP were determined following the AOAC methods [20], respectively. The AA concentrations were determined using pre-column derivatization with ACCQ reagent (6-aminoquinolyl-N-hydroxysuc-cinimidyl carbamate, Waters, Milford, MA, USA) and high-performance liquid chromatography [5]. Cysteine and methionine were analysed as cysteic acid and methionine sulfone by oxidation with performic acid for $16 \mathrm{~h}$ at $0^{\circ} \mathrm{C}$. Serum concentrations of total protein (TP), albumin (ALB), uric acid (UA), and triglycerides (TG) were analysed by an automated chemistry analyser (Hitachi 902 Automatic Analyser; Hitachi, Tokyo, Japan) using commercial test kits (Roche Diagnostics, Basel, Switzerland).

\section{Statistical analysis}

The effects of CP level, enzyme supplementation and their interactions with growth performance, serum biochemical profile, carcass traits, intestinal morphology, and pancreatic and intestinal protease activity were analysed using the general linear models procedure in SAS (SAS Institute Inc., Cary,
NC, USA). Duncan's multiple range test was used to compare between means. When interactions were significant, comparisons were made within each experimental variable. The effect of decreasing protein level was portioned into linear and quadratic components using orthogonal polynomial contrasts. Mortality data were subjected to a chi-square test. The significance is considered when $\mathrm{p}<0.05$.

\section{RESULTS}

\section{Growth performance}

The effects of CP level and protease supplementation on FI, weight gain (WG), and FCR are presented in Table 2. There were no significant $(\mathrm{p}>0.05) \mathrm{CP} \times$ protease interactions for $\mathrm{FI}$, WG, or FCR except FI for $\mathrm{d} 29$ to 35 . Except during the first week of life, FI was not affected by CP level during week 2 ( $\mathrm{p}$ $=0.07)$ and $3(\mathrm{p}=0.523)$. The FI was reduced linearly during $\mathrm{d} 1$ to $7(\mathrm{p}<0.001)$ and $\mathrm{d} 22$ to $28(\mathrm{p}<0.001)$ and $\mathrm{d} 29$ to 35 (p $=0.020$ ). The weekly data also showed that WG decreased linearly and FCR increased linearly by reduction of dietary CP. However, the results of WG and FCR were not significant for $\mathrm{d} 29$ to 35. The FI and WG decreased linearly ( $<<0.001$; $\mathrm{p}<0.001)$ and FCR increased linearly $(\mathrm{p}<0.001)$ with the reduction in dietary $\mathrm{CP}$ levels during $\mathrm{d} 1$ to 35 . The effect of protease supplementation was negligible on WG and FCR during the first 2 weeks of life. But thereafter the protease supplementation improved WG and FCR. Irrespective of dietary protein level, protease supplementation improved WG and FCR during $\mathrm{d} 1$ to $21(\mathrm{p}=0.013 ; \mathrm{p}=0.002)$ and $\mathrm{d} 1$ to $35(\mathrm{p}<0.001 ; \mathrm{p}$ $=0.001)$. The FI was not affected $(\mathrm{p}>0.05)$ by supplemental protease. Neither CP level nor enzyme supplementation had a significant effect on mortality rate (Table 2).

\section{Serum biochemical profile}

The effect of dietary CP level and protease supplementation on serum biochemicals is shown in Table 3. CP×protease interactions were significant for serum levels of ALB, TG, and UA but not for serum TP. Irrespective of protease supplementation, reducing the CP level linearly decreased $(\mathrm{p}<0.001)$ serum TP. Protease supplementation did not affect serum TP $(p=0.749)$. Serum ALB was linearly decreased by the dietary $\mathrm{CP}$ level reduction in both diets with and without protease $(\mathrm{p}<$ $0.001, p=0.042$, respectively) but was otherwise noted for TG and UA (Table 4). The level of TG increased linearly $(p<0.001)$ with the reduction of dietary $\mathrm{CP}$ in the protease supplemented group. Within the non-protease-supplemented group, the level of UA decreased linearly $(\mathrm{p}<0.001)$ and quadratically $(\mathrm{p}<0.07)$.

\section{Carcass traits}

The CP level $\times$ protease interactions for carcass traits were not significant (Table 5). Reducing dietary CP linearly decreased the dressed yield $(\mathrm{p}<0.001)$ and breast meat $(\mathrm{p}=0.049)$ and 
Table 2. Effect of crude protein level and protease enzyme supplementation on growth performance in broiler chickens from day 1-35 ${ }^{1)}$

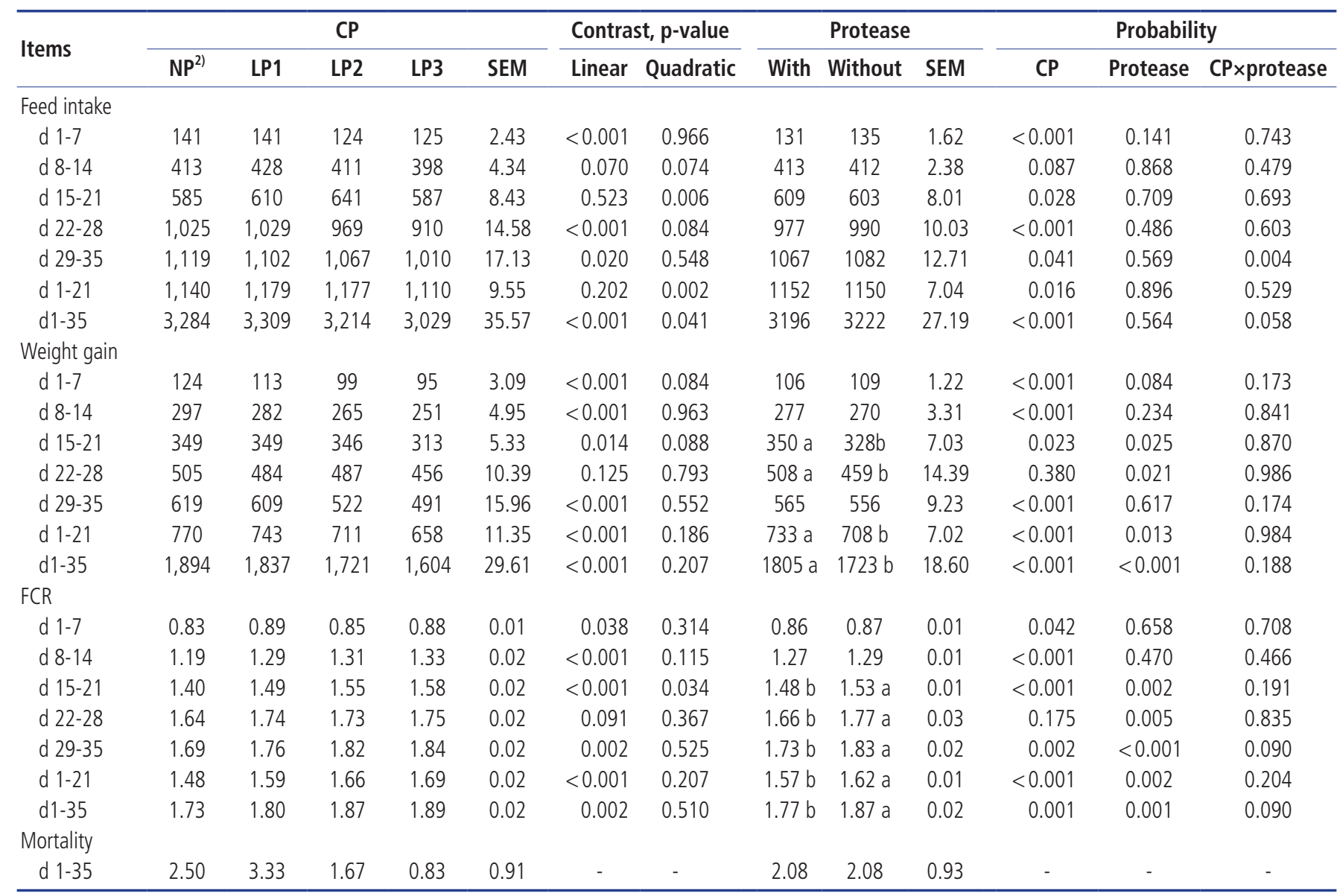

$\mathrm{CP}$, crude protein; SEM, standard error of mean; $F C R$, feed conversion ratio.

1) Data represent mean values of 4 pens.

2) NP, normal protein (starter CP21/finisher CP19); LP1, low protein diet 1 (starter CP19.7/finisher CP17.9); LP2, low protein diet 2 (starter CP18.5/finisher CP16.7); LP3, low protein diet 3 (starter CP17.2/finisher CP15.6).

a,b Means within a row-subgroup without common superscripts differ at $p<0.05$.

conversely increased the abdominal fat $(\mathrm{p}<0.001)$, regardless of protease supplementation. Protease supplementation increased carcass yield $(\mathrm{p}=0.042)$, irrespective of dietary CP level. However, percentages of breast meat and abdominal fat pad were unaffected by protease supplementation.

\section{Gut morphology}

The effects of dietary $\mathrm{CP}$ level and protease supplementation on the $\mathrm{VH}, \mathrm{CD}, \mathrm{VH} / \mathrm{CD}$ ratio and ASA in the duodenum, jejunum and ileum are displayed in Table 6. No significant $\mathrm{CP} \times$ protease interactions were noted for duodenal $\mathrm{VH}, \mathrm{CD}$, $\mathrm{VH} / \mathrm{CD}$, and ASA, jejunal CD, $\mathrm{VH} / \mathrm{CD}$ ratio and ASA and ileal VH, CD and VH/CD. However, significant CP level× protease interactions were found for jejunal $\mathrm{VH}$ and ileal ASA $(\mathrm{p}=0.036)$. Irrespective of $\mathrm{CP}$ level, protease supplementation significantly increased duodenal ASA $(\mathrm{p}<0.001)$, jejunal VH/ CD ratio $(\mathrm{p}<0.001)$ and ASA $(\mathrm{p}<0.001)$ and ileal VH $(\mathrm{p}<0.001)$. However, protease supplementation reduced jejunal CD ( $p$
$=0.008)$. Regardless of protease supplementation, jejunal $\mathrm{VH}$ $(\mathrm{p}<0.001), \mathrm{VH} / \mathrm{CD}(\mathrm{p}=0.004)$ and ASA $(\mathrm{p}<0.001)$ and ileal $\mathrm{CD}(\mathrm{p}<0.001)$ decreased quadratically. However, ileal VH/CD increased quadratically $(p=0.020)$ with the reduction in dietary CP. In contrast, reducing dietary $\mathrm{CP}$ had no effect on duodenum VH/CD and ASA ( $\mathrm{p}>0.05$ ). Jejunal VH decreased linearly $(\mathrm{p}<0.001)$ and quadratically $(\mathrm{p}<0.001)$ with protease in LP diets, but only a quadratic decrease was observed when protease was supplemented. Ileal ASA increased linearly $(\mathrm{p}=$ 0.001 ) when protease was added to LP diets, whereas a quadratic decrease $(p=0.004)$ was observed among those without supplemental protease (Table 7).

\section{Enzyme activity}

No significant $\mathrm{CP}$ level $\times$ protease interactions were observed in pancreatic or intestinal protease activity (Table 8). Protease supplementation increased $(\mathrm{p}<0.001)$ intestinal protease activity and decreased $(\mathrm{p}=0.041)$ pancreatic protease activity. 
Table 3. Effect of crude protein level and protease enzyme supplementation on serum biochemical profile in broiler chickens at 35 days of age ${ }^{1)}$

\begin{tabular}{lcccc}
\hline Item & $\begin{array}{c}\text { Albumin } \\
(\mathbf{g} / \mathbf{L})\end{array}$ & $\begin{array}{c}\text { Triglycerides } \\
(\mathbf{m m o l} / \mathbf{L})\end{array}$ & $\begin{array}{c}\text { Total protein } \\
(\mathbf{g} / \mathbf{L})\end{array}$ & $\begin{array}{c}\text { Uric acid } \\
(\boldsymbol{\mu m o l} / \mathbf{L})\end{array}$ \\
\hline Diets $)^{2)}$ & & & & \\
NP & 11.88 & 0.54 & 30.11 & 248 \\
LP1 & 11.33 & 0.74 & 26.83 & 219 \\
LP2 & 10.93 & 0.76 & 26.59 & 249 \\
LP3 & 9.73 & 0.86 & 23.78 & 150 \\
SEM & 0.21 & 0.04 & 0.54 & 11.62 \\
Contrast, p-values & & & & \\
Linear & $<0.001$ & 0.011 & $<0.001$ & 0.167 \\
Quadratic & 0.314 & 0.531 & 0.777 & 0.146 \\
Protease & & & & \\
With & 10.97 & 0.77 & 26.69 & $242^{\mathrm{a}}$ \\
Without & 10.96 & 0.68 & 26.96 & $201^{\mathrm{b}}$ \\
SEM & 0.18 & 0.04 & 0.43 & 9.75 \\
Probabilities & & & & \\
CP & $<0.001$ & 0.017 & $<0.001$ & $<0.001$ \\
Protease & 0.992 & 0.141 & 0.749 & 0.009 \\
CP $\times$ protease & 0.048 & $<0.001$ & 0.320 & $<0.001$ \\
\hline
\end{tabular}

SEM, standard error of mean; $C P$, crude protein.

1) Data represent mean values of 8 birds.

${ }^{2)} \mathrm{NP}$, normal protein (starter CP21/finisher CP19); LP1, low protein diet 1 (starter CP19.7/finisher CP17.9); LP2, low protein diet 2 (starter CP18.5/finisher CP16.7); LP3, low protein diet 3 (starter CP17.2/finisher CP15.6).

a,b Means within a column-subgroup without common superscripts differ at $p<0.05$.

Neither pancreatic nor intestinal protease activity was affected by dietary CP level.

\section{DISCUSSION}

Hot and relatively humid environmental constraint can generate a state of physiological and behavioural stress that might
Table 5. Effect of crude protein level and protease enzyme supplementation on carcass traits (as \% of live weight) in broiler chickens at 36 days of age ${ }^{1)}$

\begin{tabular}{lccc}
\hline Item & $\begin{array}{c}\text { Eviscerated }^{2)} \\
(\%)\end{array}$ & $\begin{array}{c}\text { Breastmeat } \\
(\%)\end{array}$ & $\begin{array}{c}\text { Abdominal fat } \\
(\%)\end{array}$ \\
\hline Diets $)^{4)}$ & & & \\
NP & 71.47 & 32.95 & 3.05 \\
LP1 & 70.67 & 32.08 & 3.19 \\
LP2 & 70.51 & 31.48 & 3.80 \\
LP3 & 69.33 & 31.71 & 3.81 \\
SEM & 0.22 & 0.24 & 0.09 \\
Contrast, p-values & & & \\
Linear & $<0.001$ & 0.049 & $<0.001$ \\
Quadratic & 0.653 & 0.263 & 0.651 \\
Protease & & & \\
With & $70.90^{\mathrm{a}}$ & 32.36 & 3.39 \\
Without & $70.09^{\mathrm{b}}$ & 31.75 & 3.53 \\
SEM & 0.21 & 0.28 & 0.08 \\
Probabilities & & & \\
CP & 0.003 & 0.158 & $<0.001$ \\
Protease & 0.042 & 0.208 & 0.366 \\
CP $\times$ protease & 0.237 & 0.452 & 0.868 \\
\hline
\end{tabular}

SEM, standard error of mean; $C P$, crude protein.

1) Data represent mean value of 8 birds.

${ }^{2)}$ Carcass with abdominal fat, lungs and kidneys, but without giblets, paws and head.

${ }^{3)}$ Tissue surrounding the gizzard and intestines, extending within the scheme, neighbouring the cloaca and bursa of fabricius, and adjoining the abdominal muscle.

${ }^{4)} \mathrm{NP}$, normal protein (starter CP21/finisher CP19); LP1, low protein diet 1 (starter CP19.7/finisher CP17.9); LP2, low protein diet 2 (starter CP18.5/finisher CP16.7): LP3, low protein diet 3 (starter CP17.2/finisher CP15.6).

$a, b$ Means within a column-subgroup without common superscripts differ at $p<0.05$.

affect the nutrient requirement in broiler chickens which evoke a negative effect on their productive performance, immunity and survivability [7]. Beneficial use of LP diets with supple-

Table 4. Albumin, triglycerides, and uric acid in broiler chickens at 35 days of age when interactions between crude protein level and protease enzyme supplementation were significant ${ }^{1)}$

\begin{tabular}{|c|c|c|c|c|c|c|c|}
\hline \multirow{2}{*}{ Serum metabolites } & \multicolumn{5}{|c|}{ Diets $^{2)}$} & \multicolumn{2}{|c|}{ Contrast, $p$-values } \\
\hline & NP & LP1 & LP2 & LP3 & SEM & Linear & Quadratic \\
\hline \multicolumn{8}{|l|}{ Albumin (g/L) } \\
\hline With protease & 12.09 & 11.54 & 11.29 & 8.95 & 0.31 & $<0.001$ & 0.060 \\
\hline Without protease & 11.66 & 11.13 & 10.56 & 10.50 & 0.22 & 0.042 & 0.581 \\
\hline \multicolumn{8}{|l|}{ Triglycerides (mmol/L) } \\
\hline With protease & 0.42 & 0.68 & 0.86 & 1.23 & 0.07 & $<0.001$ & 0.630 \\
\hline Without protease & 0.68 & 0.81 & 0.66 & 0.59 & 0.04 & 0.278 & 0.242 \\
\hline \multicolumn{8}{|l|}{ Uric acid (umol/L) } \\
\hline With protease & 182 & 290 & 323 & 159 & 15.71 & 0.717 & $<0.001$ \\
\hline Without protease & 315 & 157 & 164 & 141 & 16.42 & $<0.001$ & 0.007 \\
\hline
\end{tabular}

SEM, standard error of mean.

1) Data representmean value of 8 birds.

${ }^{2)}$ NP, normal protein (starter CP21/finisher CP19); LP1, low protein diet 1 (starter CP19.7/finisher CP17.9); LP2, low protein diet 2 (starter CP18.5/finisher CP16.7); LP3, low protein diet 3 (starter CP17.2/finisher CP15.6). 
Table 6. Effect of crude protein level and protease enzyme supplementation on small intestinal morphology in broiler chickens at 35 days of age"

\begin{tabular}{|c|c|c|c|c|c|c|c|c|c|c|c|c|}
\hline \multirow[b]{2}{*}{ Item } & \multicolumn{4}{|c|}{ Duodenum } & \multicolumn{4}{|c|}{ Jejunum } & \multicolumn{4}{|c|}{ Ileum } \\
\hline & VH $(\mathrm{mm})$ & $\mathrm{CD}(\mathrm{mm})$ & $\begin{array}{c}\mathrm{VH} / \mathrm{CD} \\
\text { ratio }(\mu \mathrm{m})\end{array}$ & ASA (mm) & VH (mm) & $\mathrm{CD}(\mathrm{mm})$ & $\begin{array}{c}\mathrm{VH} / \mathrm{CD} \\
\text { ratio }(\mu \mathrm{m})\end{array}$ & $\mathrm{ASA}(\mathrm{mm})$ & $\mathrm{VH}(\mathrm{mm})$ & $\mathrm{CD}(\mathrm{mm})$ & $\begin{array}{c}\mathrm{VH} / \mathrm{CD} \\
\text { ratio }(\mu \mathrm{m})\end{array}$ & $\begin{array}{l}\text { ASA } \\
(\mathrm{mm})\end{array}$ \\
\hline \multicolumn{13}{|l|}{ Diets $^{2)}$} \\
\hline NP & 1,501 & 189 & 8.05 & 0.383 & 1,045 & 176 & 6.09 & 0.228 & 634 & 134 & 4.88 & 0.127 \\
\hline LP1 & 1,466 & 186 & 7.99 & 0.375 & 1,012 & 169 & 6.14 & 0.245 & 652 & 138 & 4.84 & 0.163 \\
\hline LP2 & 1,411 & 197 & 7.25 & 0.392 & 914 & 179 & 5.33 & 0.179 & 606 & 119 & 5.17 & 0.134 \\
\hline LP3 & 1,559 & 182 & 8.67 & 0.408 & 797 & 167 & 5.05 & 0.149 & 597 & 110 & 5.51 & 0.124 \\
\hline SEM & 26.65 & 3.05 & 0.19 & 0.011 & 20.81 & 3.83 & 0.17 & 0.008 & 11.13 & 3.48 & 0.10 & 0.004 \\
\hline \multicolumn{13}{|l|}{ Contrast, p-values } \\
\hline Linear & 0.854 & 0.416 & 0.412 & 0.946 & 0.055 & 0.427 & 0.930 & 0.676 & 0.636 & 0.993 & 0.813 & 0.005 \\
\hline Quadratic & 0.976 & 0.721 & 0.860 & 0.443 & $<0.001$ & 0.960 & 0.004 & $<0.001$ & 0.055 & $<0.001$ & 0.020 & 0.041 \\
\hline \multicolumn{13}{|l|}{ Protease } \\
\hline With & 1,532 & 188 & 8.25 & $0.432^{\mathrm{a}}$ & 960 & $161^{b}$ & $6.16^{a}$ & $0.219^{a}$ & $663^{\mathrm{a}}$ & 129 & 5.26 & $0.146^{a}$ \\
\hline Without & 1,436 & 189 & 7.72 & $0.346^{b}$ & 923 & $184^{a}$ & $5.15^{b}$ & $0.182^{b}$ & $582^{b}$ & 121 & 4.93 & $0.128^{b}$ \\
\hline SEM & 17.94 & 1.71 & 0.12 & 0.014 & 9.20 & 5.34 & 0.20 & 0.006 & 13.34 & 3.78 & 0.09 & 0.003 \\
\hline \multicolumn{13}{|l|}{ Probabilities } \\
\hline$C P$ & 0.220 & 0.431 & 0.025 & 0.805 & $<0.001$ & 0.730 & 0.016 & $<0.001$ & 0.141 & 0.053 & 0.060 & $<0.001$ \\
\hline Protease & 0.062 & 0.977 & 0.099 & $<0.001$ & 0.090 & 0.008 & $<0.001$ & $<0.001$ & $<0.001$ & 0.232 & 0.086 & 0.008 \\
\hline $\mathrm{CP} \times$ protease & 0.299 & 0.179 & 0.085 & 0.661 & $<0.001$ & 0.532 & 0.621 & 0.173 & 0.258 & 0.555 & 0.093 & 0.036 \\
\hline
\end{tabular}

$\mathrm{VH}$, villus height; $\mathrm{CD}$, crypt depth; $A S A$, absorptive surface area; $S E M$, standard error of mean; $C P$, crude protein.

1) Data represent mean value of 8 birds.

2) NP, normal protein (starter CP21/finisher CP19); LP1, low protein diet 1 (starter CP19.7/finisher CP17.9); LP2, low protein diet 2 (starter CP18.5/finisher CP16.7); LP3, low protein diet 3 (starter CP17.2/finisher CP15.6).

a,b Means within a column-subgroup without common superscripts differ at $p<0.05$.

mental EAA in a hot-weather has been reported [5,6]. In the present study, despite meeting the requirement for lysine, methionine+cysteine, tryptophan and threonine in LP diets, WG and FCR were depressed throughout the experimental period, regardless of protease supplementation. Reduction of growth performance in broilers fed LP diets and supplemented with EAA has been reported [5] irrespective of their environmental condition, and this reduction could be associated with lower levels of specific NEAA such as glycine and serine or glutamic acid, or with anon-specific need for nitrogen [6]. Earlier work on AA-supplemented LP diets in a hot environment
[5] suggested that reduced FI could be a possible explanation for the inferior WG. The reduced FI was noted as a quadratic effect in this study, where only higher levels of $\mathrm{CP}$ reduction (LP2 and LP3) reduced FI markedly. This may possibly be due to one or several AA that are regulating FI other than CP concentrations per se [21]. Although protease supplementation improved WG and FCR, it failed to alter the linear reduction of WG and the increment of FCR incurred by reducing CP. This could be partly due to the lack of protease effect on FI. The protease used in this study was previously shown to enhance proteins, AAs and energy digestibility in broilers fed

Table 7. Intestinal morphology in broiler chickens at 35 days of age when interactions between crude protein level and protease enzyme supplementation were significant ${ }^{1)}$

\begin{tabular}{|c|c|c|c|c|c|c|c|}
\hline \multirow{2}{*}{ Item } & \multicolumn{4}{|c|}{ Diets $^{2)}$} & \multirow{2}{*}{ SEM } & \multicolumn{2}{|c|}{ Contrast, p-values } \\
\hline & NP & LP1 & LP2 & LP3 & & Linear & Quadratic \\
\hline \multicolumn{8}{|l|}{ Jejunal villus height } \\
\hline Without protease & 962 & 1063 & 871 & 798 & 22.95 & 0.099 & $<0.001$ \\
\hline \multicolumn{8}{|c|}{ Ileal absorptive surface area } \\
\hline With protease & 0.119 & 0.174 & 0.151 & 0.142 & 0.066 & $<0.001$ & 1.000 \\
\hline
\end{tabular}

SEM, standard error of mean.

1) Data represent mean value of 8 birds.

2) NP, normal protein (starter CP21/finisher CP19); LP1, low protein diet 1 (starter CP19.7/finisher CP17.9); LP2, low protein diet 2 (starter CP18.5/finisher CP16.7); LP3, low protein diet 3 (starter CP17.2/finisher CP15.6). 
Table 8. Effect of crude protein level and protease enzyme supplementation on endogenous protease activity in broiler chickens at 35 days of age ${ }^{1)}$

\begin{tabular}{lcc}
\hline Item & Pancreas & Small intestinal \\
\hline Diets $^{2)}$ & & \\
NP & 138.3 & 85.9 \\
LP1 & 132.5 & 84.5 \\
LP2 & 144.7 & 86.4 \\
LP3 & 143.5 & 85.8 \\
SEM & 2.21 & 1.65 \\
Contrast, p-values & & \\
Linear & 0.103 & 0.947 \\
Quadratic & 0.541 & 0.936 \\
Protease & & \\
With & $136.0^{\mathrm{b}}$ & $98.3^{\mathrm{a}}$ \\
Without & $143.6^{\mathrm{a}}$ & $73.0^{\mathrm{b}}$ \\
SEM & 2.23 & 3.65 \\
Probabilities & & \\
CP & 0.082 & 0.983 \\
Protease & 0.041 & $<0.001$ \\
CP $\times$ protease & 0.319 & 0.372 \\
\hline
\end{tabular}

SEM, standard error of mean; $C P$, crude protein.

1) Data represent mean value of 8 birds.

2) NP, normal protein (starter CP21/finisher CP19); LP1, low protein diet 1 (starter CP19.7/finisher CP17.9); LP2, low protein diet 2 (starter CP18.5/finisher CP16.7); LP3, low protein diet 3 (starter CP17.2/finisher CP15.6).

a,b Means within a column-subgroup without common superscripts differ at $p<0.05$.

different protein levels [12]. Therefore, the observed improvements in nutrient digestibility and nutrient retention $[15,17,22]$ in birds fed diets containing exogenous protease may have beneficial effects on body weight. This finding is in accordance with those reported by Angel et al [11] and Mahmood et al [10], where supplementation of mono-component protease improved growth performance in broilers.

The data showed that descending levels of dietary CP reduced the concentrations of ALB and TP, irrespective of protease supplementation. Blood plasma TP and ALB are the main transport proteins in avian species, and they reflect the avian nutritional condition [23]. The reduction in serum TP and ALB could be attributed to deficiency in AA intake by the birds, as measured by the lower FI [5]. The linear reduction of FI (day 1 to 35) in our study may have accounted for the decreased UA level with the reduction in dietary CP level. The UA is a by-product of protein catabolism and turnover in the body. Thus, the decrease in UA could be associated with a deficiency of ingested AA. Furthermore, UA reduction may also be related to glycine deficiency, the substrate of UA synthesis in the liver [2,3]. It is interesting to note that the linear reduction in UA with decreasing dietary CP level was only noted among those without protease supplementation. It appears that protease supplementation may have released glycine in the digestive system and therefore compensated the shortage of glycine in LP diets [12]. On the other hand, serum TG was not affected by reduced protein diets containing no protease. However, decreasing CP with supplemental protease increased serum TG. This finding is in contrast to the findings of Abudabos [24]. The author fed broiler chickens with a commercial enzyme cocktail (protease and carbohydrase) and observed that enzyme supplementation has no effect on serum TG. This discrepancy may be due to the different types of enzyme used.

As expected, carcass and breast meat yield decreased, and the rate of abdominal fat deposition was significantly higher in birds that were fed LP diets in this study. Most of the previous studies reported the same phenomenon in broilers fed with LP diets [3,24]. This is due to a higher calorie:protein ratio in LP diets. It appears that the excess available energy beyond that required for protein deposition is diverted to abdominal fat deposition. Interestingly, although protease supplementation did not change the rate of fat deposition, it improved the carcass yield. There are conflicting reports on the effect of protease supplementation on carcass yield. While Rehman et al [22] noticed no significant change in carcass yield or abdominal fat, Abudabos [24] reported an increase in carcass and breast meat yield. The improvement in carcass yield associated with protease supplementation could be due to enhanced utilization and deposition of protein [23].

The present results concur with earlier work that reducing dietary $\mathrm{CP}$ was detrimental to gastrointestinal tract morphometry [4]. The decrease in the intestinal VH, VH/CD, and ASA is associated with poor nutrient absorption and consequently depressed growth performance in broiler chickens [17]. The adverse effect of LP diets on gut morphometry could be attributed to a decrease in the concentrations of NEAA such as glycine, glutamine and proline, which actively support the epithelial layer and represent a major fraction of intestinal masons and digestive secretions [25]. In contrast, protease supplementation significantly increased duodenal and jejunal ASA and jejunal VH/CD ratios and ileal VH. The present findings are in agreement with Cowieson et al [15], Ding et al [9] and $\mathrm{Xu}$ et al [17]. These results indicated that more nutrients were digested by supplemental protease $[9,11]$, and most likely, the extra energy absorbed was used to improve the intestinal morphology.

It was noted that the reduction in dietary $\mathrm{CP}$ level did not alter pancreatic or intestinal protease activity in the present study. Ding et al [9], however, reported otherwise. On a cautionary note, Ding et al [9] reduced CP (21\%, 20\%, and 19\% during starter and $19 \%, 18 \%$, and $17 \%$ during grower phase) and supplemented with AA (lysine, threonine, and methionine). However, the calculated and analysed AA were lowered in LP diets. Thus, the discrepancy between pancreatic and intestinal protease activities may be due to insufficient supplementation of AA. The current results confirmed those of Mahagna et al [13], which showed that enzyme supplementation (protease and amylase at higher dosage, 1,000 ppm) 
suppressed endogenous pancreatic protease activity. Exogenous proteases may augment endogenous peptidases by increasing protein digestibility and hydrolysing proteinaceous antinutritional factors. In contrast, Ding et al [9] fed broiler chickens with three levels of protease $(0,150$, and $300 \mathrm{ppm})$ and observed that protease concentration has no effect on either pancreatic or small intestinal protease activity at $\mathrm{d} 21$. However, protease (at $300 \mathrm{ppm}$ ) significantly increased pancreatic protease activity at $\mathrm{d} 42$. These inconsistencies could be attributed to variations in the age of birds, the dosage, or the type of protease used [26].

\section{CONCLUSION}

The present findings demonstrated that protease supplementation at the rate used in this study may offset the detrimental effects caused by reducing dietary CP on growth performance, intestinal morphology and carcass yield in broiler chickens raised under a hot and humid tropical condition. The magnitude of compensation may depend on the type and dosage of protease supplemented.

\section{CONFLICT OF INTEREST}

We certify that there is no conflict of interest with any financial organization regarding the material discussed in the manuscript.

\section{ACKNOWLEDGMENTS}

This study was supported by the Malaysian Ministry of Higher Education under the Long-term Research Grant Scheme.

\section{REFERENCES}

1. Bregendahl K, Sell JL, Zimmerman DR. Effect of low protein diets on growth performance and body composition of broiler chicks. Poult Sci 2002;81:1156-67.

2. Waldroup PW, Jiang Q, Fritts C. Effects of supplementing broiler diets low in crude protein with essential and nonessential amino acids. Poult Sci 2005;4:425-31.

3. Namroud NF, Shivazad M, Zaghari M. Effects of fortifying low crude protein diet with crystalline amino acids on performance, blood ammonia level, and excreta characteristics of broiler chicks. Poult Sci 2008;87:2250-8.

4. Laudadio V, Passantino L, Perillo A, et al. Productive performance and histological features of intestinal mucosa of broiler chickens fed different dietary protein levels. Poult Sci 2012; 91:265-70.

5. Awad EA, Zulkifli I, Soleimani AF, Loh TC. Amino acids fortification of low-protein diet for broilers under tropical climate. 2. Nonessential amino acids and increasing essential amino acids. Italian J Anim Sci 2014;13:631-6.

6. Awad EA, Zulkifli I, Soleimani AF, Aljuobori A. Effects of feeding male and female broiler chickens on low-protein diets fortified with different dietary glycine levels under the hot and humid tropical climate. Italian J Anim Sci 2017;16:453-61.

7. Temim S, Chagneau AM, Guillaumin S, et al. Effects of chronic heat exposure and protein intake on growth performance, nitrogen retention and muscle development in broiler chickens. Reprod Nutr Dev 1999;39:145-56.

8. Cowieson AJ, Ravindran V. Effect of exogenous enzymes in maize based diets varying in nutrient density for young broilers: growth performance and digestibility of energy, minerals and amino acids. Br Poult Sci 2008;49:37-44.

9. Ding XM, Li DD, Li ZR, et al. Effects of dietary crude protein levels and exogenous protease on performance, nutrient digestibility, trypsin activity and intestinal morphology in broilers. Livest Sci 2016;193:26-31.

10. Mahmood T, Mirza M, Nawaz H, et al. Effect of supplementing exogenous protease in low protein poultry by-product meal based diets on growth performance and nutrient digestibility in broilers. Anim Feed Sci Technol 2017;228:23-31.

11. Angel C, Saylor W, Vieira S, Ward N. Effects of a monocomponent protease on performance and protein utilization in 7-to 22-day-old broiler chickens. Poult Sci 2011;90:2281-6.

12.Law FL, Zulkifli I, Soleimani AF, Hossain M, Liang JB. Nutrient digestibility of broiler chickens fed on a low-protein diet supplemented with mono-component proteases. Eur Poult Sci 2015;79:107.

13. Mahagna M, Nir I, Larbier M, Nitsan Z. Effect of age and exogenous amylase and protease on development of the digestive tract, pancreatic enzyme activities and digestibility of nutrients in young meat-type chicks. Reprod Nutr Dev1995;35:201-12.

14. Yegani M, Korver DR. Effects of corn source and exogenous enzymes on growth performance and nutrient digestibility in broiler chickens. Poult Sci 2013;92:1208-20.

15. Cowieson A, Zaefarian F, Knap I, Ravindran VR. Interactive effects of dietary protein concentration, a mono-component exogenous protease and ascorbic acid on broiler performance, nutritional status and gut health. Anim Produ Sci 2016;57: 1058-68.

16. Kamel NF, Ragaa NM, El-Banna RA, Mohamed FF. Effects of a monocomponent protease on performance parameters and protein digestibility in broiler chickens. Agric Agric Sci Procedia 2015;6:216-25.

17.Xu X, Wang HL, Pan L, et al. Effects of coated proteases on the performance, nutrient retention, gut morphology and carcass traits of broilers fed corn or sorghum based diets supplemented with soybean meal. Anim Feed Sci Technol 2017;223:119-27.

18. Marchini CFP, Café MB, Araújo EG, Nascimento MRBM. Physiology, cell dynamics of small intestinal mucosa, and performance of broiler chickens under heat stress: a review. 
Rev Colom Cienc Pecua 2016;29:159-68.

19. Jin L, Ho Y, Abdullah N, Jalaludin S. Digestive and bacterial enzyme activities in broilers fed diets supplemented with Lactobacillus cultures. Poult Sci 2000;79:886-91.

20.AOAC (Association of Official Analytical Chemists) international. Official methods of analysis. 17th ed. Association of Official Analytical Chemist. Arlington, VA, USA: AOAC International; 2000.

21.Sklan D, Plavnik I. Interactions between dietary crude protein and essential amino acid intake on performance in broilers. Br Poult Sci 2002;43:442-9.

22. Rehman Z, Kamran J, El-Hack MA, et al. Influence of lowprotein and low-amino acid diets with different sources of protease on performance, carcasses and nitrogen retention of broiler chickens. Anim Prod Sci 2017 Mar 30 [Epub]. https:// doi.org/10.1071/AN16687
23.Lauri A, Hanauska-Brown, Alfred M, Dufty JR. Blood chemistry, cytology and body condition in adult northern goshawks. J Raptor Res 2003;37:299-306.

24. Abudabos AM. Effect of enzyme supplementation to normal and low density broiler diets based on corn-soybean meal. Asian J Anim Vet Adv 2012;7:139-48.

25.Lensing M, Van Der Klis J, Le bellego L, Rovers M. The threonine requirement of broiler chickens during subclinical intestinal infection. In: Proceedings of the 16th European Symposium on Poultry Nutrition 2007; 2007 August 26-30; Strasbourg, France: World Poultry Science Association; 2007. p. 343-6.

26. Ghazi S, Rooke JA, Galbraith H, Bedford MR. The potential for the improvement in the nutritive value of soya-bean meal by different proteases in broiler chicks and broiler cockerels. Br Poult Sci 2002;43:70-7. 